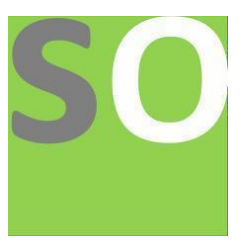

Article title: 2.2-Diphenic Acid: A Reliable Biomarker Of Phenanthrene Biodegradation

Authors: Emmanuel Fenibo[1]

Affiliations: Microbiology, University of Port Harcourt, Nigeria[1]

Orcid ids: 0000-0003-3017-6579[1]

Contact e-mail: feniboe1478@gmail.com

License information: This work has been published open access under Creative Commons Attribution License $\mathrm{http}: / / c r e a t i v e c o m m o n s . o r g / l i c e n s e s / b y / 4.0 /$, which permits unrestricted use, distribution, and reproduction in any medium, provided the original work is properly cited. Conditions, terms of use and publishing policy can be found at https://www.scienceopen.com/.

Preprint statement: This article is a preprint and has not been peer-reviewed, under consideration and submitted to ScienceOpen Preprints for open peer review.

Funder: None

DOI: 10.14293/S2199-1006.1.SOR-.PPP4HD5.v1

Preprint first posted online: 14 March 2021

Keywords: 1-hydroxy-2-naphthoic acid, 2,2'-diphenic acid, Bacteria, Intermediary metabolites, Phenanthrene, 9,10-dihydroxyphenanthrene., Metabolic pathway, Microorganisms, Polluted habitat, Petroleum hydrocarbons 


\title{
2.2'-DIPHENIC ACID: A RELIABLE BIOMARKER OF PHENANTHRENE BIODEGRADATION
}

Emmanuel Oliver Fenibo

World Bank Africa Centre of Excellence, Centre for Oilfield Chemical Research, University of Port Harcourt, Nigeria

\begin{abstract}
Phenanthrene is among the 16 priority pollutant and its mitigation in the environment has been a global concern. It serves as a model compound when it comes to biodgradation study of polyaromatic hydrocarbons (PAHs) because it has both the Bay- and K-region found in most PAH pollutants. Like other PAH pollutants, different means are available for its remediation in the environment, including microbial biodegradation. Diverse species of bacteria and fungi metabolize phenanthrenes as their sole source of carbon and energy. However, bacteria are more diverse in comparison to fungi. This has been shown in published pathways of phenanthrene biodegradation implicating various intermediary metabolites, including 2,2'-diphenic acid, which is a downline metabolite of 9,10dihydroxyphenanthrene. Though the 2,2'-diphenic acid has been widely demonstrated to produce carbon (iv) oxide and linked to phthalate, only few has traced salicylic acid as its downstream molecule. 2,2'-diphenic acid mounts equivalent position to 1-hydroxy-2-naphthoic acid, metabolite that ends the phenanthrene metabolic pathway. This is because they both produce phthalic acid and salicylic acid. As a product of bacteria and fungi during phenanthrene degradation, 2,2'-diphenic acid can serve as a dependable biomarker of phenanthrene metabolism in a polluted habitat, where microbial community exist freely.
\end{abstract}

Keywords: 1-hydroxy-2-naphthoic acid; 2,2'-diphenic acid; Bacteria; Intermediary metabolites; Phenanthrene;

\section{Introduction}

Phenanthrenes are polyaromatic hydrocarbons with three-fused benzene rings in angular configuration. They are isomers of anthracenes but are more stable due to the efficient $\pi$-bonding (Pradhan et al., 2020). Their physical properties makes them to be insoluble and form hydrophobic films that block sunlight and air penetration. In addition to their chemical properties, they cause reduction of microbial biomass, negatively affect plant growths, compromise ecological services and are toxic to fish and algae (Zindler et al., 2016; Xin et al., 2020). Consequently, they are included among the 16 priority pollutants (Bhyyan and Giri, 2020). Though phenanthrenes are man-made, they also occur naturally in higher plants, crude oil and coal in different derivatives (Kusz et al., 2021). Besides, they are used in making drugs, dyes and pesticides (Mangwani et al., 2014).

Phenanthrenes as environmental pollutants requires mitigation from the environment. One trending method of achieving this is through microbial degradation, the science behind bioremediation technology. Biodegradation of phenanthrenes follows divers pathways but the most dominant one starts with deoxygenation at the 3,4 position to form cis-phenanthrene dihydrodiol then to the formation of 3,4-dihydroxyphenanthrene (Pagnout et al., 2007). Through series of reactions, including ring cleavage reactions, 1-hydroxy-2-naphthoic acid is formed which in turn lead to protocatechuic acid and salicylic acid (Gao et al., 2013). The formation of 1-hydroxy-2-naphthoic acid terminates the upper catabolic pathway of phenanthrene degradation (Habe and Omori, 2003).

A link has been shown between 9,10-dihydroxyphenanthrene, 2,2-diphenic acid and phthalic acid but downstream metabolites of 2,2-diphenic acid has not been widely publicized. Both bacteria and fungi induced biodegradation of phenanthrene has shown to produce 2,2-diphenic acid, hence can serve as a reliable biomarker of phenanthrene biodegradation driven by unrestricted microbial community.

Phenanthrenes: definition, physical properties and sources 
Phenanthrenes are low molecular weight species of polyaromatic hydrocarbons (PAHs) that are composed of three fused benzene rings in angular arrangement. They appear as yellow/white crystalline compounds. It is important to note that anthracene is also a three-fused benzene rings but in planar structure. This makes anthracenes and phenanthrenes to be structural isomers. Beside, phenanthrenes are more stable due to the $\pi$-bonding efficiency (Poater et al., 2018). Their physical properties are listed below:

$\begin{array}{ll}\text { Appearance: } & \text { Yellow/white crystals } \\ \text { Molecular formular: } & \mathrm{C}_{14} \mathrm{H}_{10} \\ \text { Molecular mass: } & 178.23 \mathrm{~g} / \mathrm{mol} \\ \text { Density: } & 1.18 \mathrm{~g} / \mathrm{mL} \\ \text { Boiling point: } & 340{ }^{\circ} \mathrm{C} \\ \text { Melting point: } & 101^{\circ} \mathrm{C} \\ \text { Flash point: } & 171{ }^{\circ} \mathrm{C} \\ \text { Aqueous solubility: } & 1.1 \mathrm{mg} / \mathrm{L} \text { (at } 25^{\circ} \mathrm{C} \text { ) } \\ \text { Octanol/water partition coefficient ratio: } 2.9 \mathrm{x} 10^{4} \\ \text { Carcinogenicity: } 3 \text { (not classifiable) }\end{array}$

Their insolubility make them to form nonaqueous films, which hinder penetration of sunlight, block air penetration thereby creating anoxic/toxic environment. Consequently, they cause drastic changes of microbial diversity, affect healthy growth of plants and compromise ecological services. Due to their stability feature, they accumulate in living cells and through food chain they biomagnify in higher organisms. Phenanthrenes are amongst the 16 priority pollutants that are toxic to algae and fish (Waigi et al., 2015). Phenanthrenes are both natural and synthetic; and can exist in different derivatives.

Phenanthrenes occur in higher plants including but not limited to species in the Orchidaceae, Judacaceae, Dioscoreaceae, Hepatticeae, Bettulaceae and Combretaceae families. Some principal examples are Bletilla, Cymbidium, Eria, Dendrobium, Coelogyna and Bulbophyllum used as traditional medicinal plants (Kovacs et al., 2008; Shi et al., 2017; Bus et al., 2018; Kusz et al., 2021). More than 450 compounds has been described, involving monometric, dimeric and trimeric derivatives of phenanthrenes (Toth et al., 2017). Other sources of phenanthrenes are crude oil, coal derivatives, plant (for wood treatment, asphalt production, incineration) sites, combustion of woods/forests. Phenanthrene is produced in cigarette smokes and are used in making dyes, manufacturing pesticides, plastics, drugs, steroids and cholesterols (Wang et al., 2012).

\section{Phenanthrene biodegradation}

Biodegradation is the process through which biological agents and biological entities reduce metabolic compounds into smaller compounds (Ukiwe et al., 2013). According to Okpokwasili and Nkweke (2005) the ecological scenarios that condition a pollutant to be biodegraded include (1) as carbon and energy source (2) as an electron acceptor (3) been a source of other cell compound and (4) been susceptible to non-specific enzyme of growing and non-growing cells. Biodegradation of phenanthrenes are much easier in comparison to other PAHs, which have high molecular weight (Seo et al., 2009).

\section{Synopsis of PAH biodegradation}


Polyaromatic hydrocarbon microbial degradation follows a rather unique order, though the higher the number of aromatic rings the more complex the biochemical reaction becomes. The first reaction is catalyzed by dioxygenase to form cis-PAH dihydrodiol. For example, naphthalene is catalyzed by naphthalene dioxygenase (NDO) to produce $c i s-$ naphthalene dihydrodiol (Raissa et al., 2012). Cis-PAH dihydrodiol is then transformed to dihydroxyPAH by dehydrogenase. For instance cis-3,4-phenanthrene dihydrodiol is transformed into 3,4-dihydroxyphenanthrene (Pagnout et al., 2007). Similarly cis-7,8-(or 1,2-)fluoranthene dihydrodiol is converted to 7,8-(or 1,2-) dihydroxyfluoranthene (Sei et al., 2003).

By series of biochemical reactions, central metabolic compounds are formed from dihydroxyPAHs, which represent the end-point of upper catabolic pathway of PAHs and serve as the beginning of PAH lower catabolic pathway. Salicylic acid (from naphthalene), 1-hydroxy-2-naphthoic acid (from phenanthrene) and naphthalene-1,8-dicarboxylic acid (from fluoranthene) are common central metabolic compounds (Sihag and Pathak, 2014). Salicylate is catabolized into gentisate and catechol; 1-hydroxy-2-naphthoic acid is biodegraded into protocatechuic acid and salicylic acid while naphthalene-1,8-dicarboxylic acid is transformed into 2-hydroxyisopthalate (which produces salicylate) and benzene-1,2,3-tricarboxylic acid (which produces protocatechuate). Protocatechuate, salicylate and catechol are critical metabolites that are channeled into the tricarboxylic acid (TCA) cycle to yield energy for the degraders (Kumar et al., 2011). Catechol biodegradation has two established pathways-ortho and meta catabolic pathways. These two pathways are finally channeled into the central TCA cycle with the evolution of carbondioxide.

\section{Metabolic pathways of phenanthrene}

Phenanthrene is majorly catalyzed by dioxygenase (Gran-Scheuch et al., 2017; Ahmad et al., 2019; Jia et al., 2019) but the involvement of monooxygenases has been reported also. Bacterial degradation of phenanthrenes starts with the formation of isomers (9,10-; 1,2-; and 3,4-) but the cis-3,4-dihydrophenanthrene-3,4-diol isomer (Mishra et al., 2019; Yin et al., 2020) has proven to be the dominant (Fig. 1.). Cis-3,4-dihydrophenanthrene-3,4-diol is consequently transformed to 3,4-dihydroxyphenanthrene. The latter undergo series of reaction including ring cleavage to produce 1-hydroxy-2-naphthoic acid, which terminates the upper catabolic pathway of phenanthrene (Zeb et al., 2020). The hydroxynaphthoic acid takes two routes: phthalic acid and naphthalene routes. The phthalic acid pathway leads to protocatechuic acid while the naphthalene pathway leads to salicylic acid which in turn yields gentisic acid and catechol. The catechol is driven by two ring cleavage pathway: ortho cleavage pathway (with catechol-1,2dioxygenase) and meta cleavage (directed by catechol-2,3-dioxygenase) (Mawad et al., 2020). The ortho pathway yields succinyl CoA and Acetyl CoA while the meta pathway produces acetaldehyde and pyruvic acid. The gentisic degradation produces fumaric acid and pyruvic acid. The products of the salicylic degradation enters the tricarboxylic acid cycle, which ultimately produces carbondioxide (Bai et al., 2021; Zhou et al., 2021).

Fungi also degrade phenanthrene but not as diverse as bacteria. The most documented phenanthrene degradation by fungi is the 9,10-dioxygenase pathway to produce 2,2-diphenic acid (Gupta et al., 2021). Initially it was thought that only fungi can produce 2,2-diphenic acid from phenanthrene degradation. But subsequent study has shown that some species of bacteria also produce 2,2-diphenic acid The diphenic acid is a downstream product of 9,10dihydroxyphenanthrene (Mishra et al., 2019). Overall, more that 33 metabolites from phenanthrene degradation has been reported (Seo et al., 2009) 


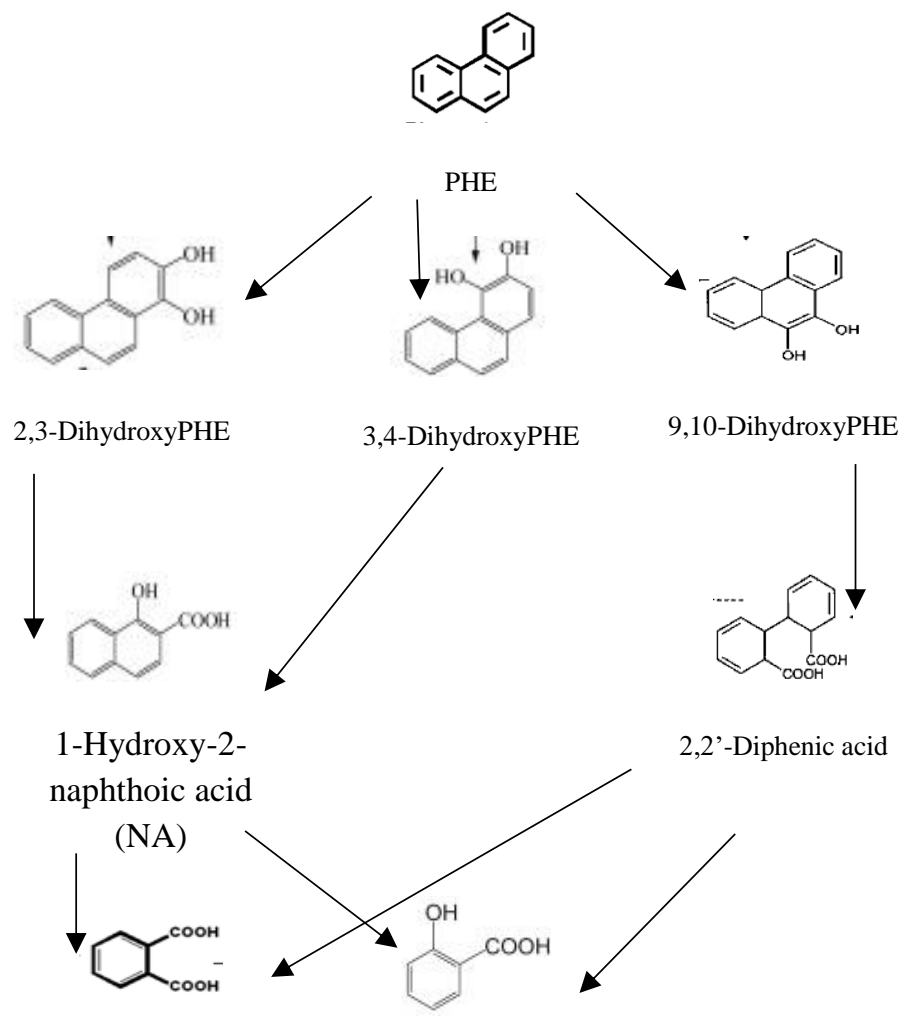

Phthalic acid Salicylic acid
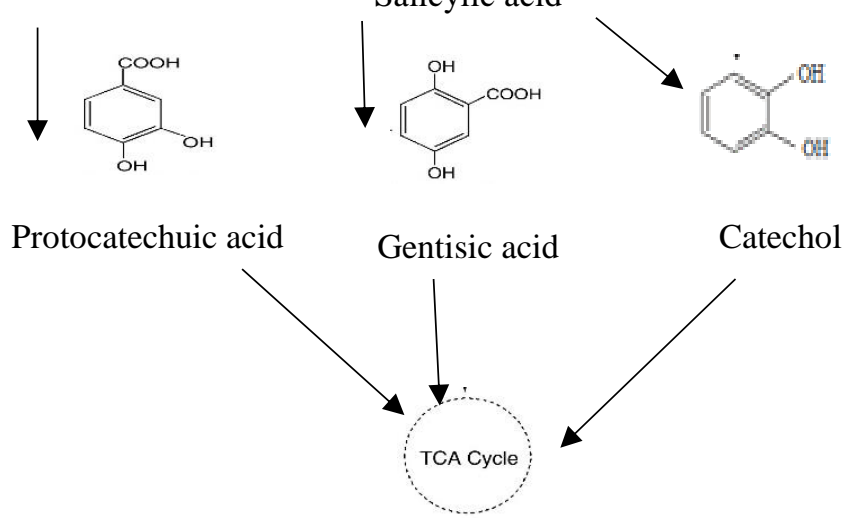

Fig. 1. A simplified phenanthrene biodegradation pathway, with each arrow representing multiple reactions (Adapted from Seo et al., 2009; Huang et al., 2016; Pandey et al., 2016) 


\section{Factors affecting biodegradation of phenanthrene hydrocarbon}

Phenanthrene degradation, like other PAHs, are affected by diverse factors that rely on three basic categories: chemical nature of pollutants, environmental factors and biological factors.

\section{Nature of chemical compound}

Factors associated with the chemical nature of phenanthrene are molecular structure, concentration, bioavailability and toxicity of intermediary metabolites. Phenanthrene has both Bay- and K-region, thus can be used as a model to study biodegradation PAHs with higher molecular weight possessing the Bay- and K-region. Besides, phenanthrene as low molecular weight (corresponding with lower electrochemical stability; Semple et al., 2003) PAH is easy to be metabolized by microorganisms (Esadefa et al.,2015). In comparison to its linear isomer, phenanthrene is more stable because of its angular structure (Atagana et al., 2003). Concentration of phenanthrene also affects its degradation. The higher the concentration, the more it affects the degraders with the result of reduced removal (Strand et al., 2007). Bioavailabilty enhances biodegradation of phenanthrene (Becher et al., 2000). Thus, synthetic surfactants or biosurfactants can lead to higher rate of phenanthrene degradation. Some microorganisms are adapted to producing biosurfactants real-time, making them to be expert degraders of phenanthrenes. Oxy-compounds (ketones, quinones and coumarins (7,8-benzocoumarine)) from phenanthrene degradation often leads to poor phenanthrene degradation because they are more toxic than the phenanthrene (Lundstedt et al., 2003).

\section{Biological factors}

The ability of microbial community to degrade PAHs rests on the number of competent microorganisms. Bacterial number of less than $1 \times 10^{3} \mathrm{CFU} / \mathrm{g}$ will cause the persistence of phenanthrenes, like other PAHs (Petrovic et al., 2008). Table 1 displays examples of bacteria that degrade phenanthrenes. A range of $10^{4}$ to $10^{7} \mathrm{CFU} / \mathrm{g}$ represents a hopeful number of microbial populations for biodegradation of phenanthrenes and other hydrocarbons. Communities of competent microorganisms constituted by different phenotypes degrade phenanthrenes much faster and efficiently (Vinas et al., 2005). For instance, a community of microorganism consisting of fungi, algae and bacteria according to Rajaei et al. (2011) degrade pollutants faster than a community of bacteria only. This is due to the release of enzymes that degrade the pollutants through metabolic pathways as a carbon and energy source (Igwo-Ezikpe et al., 2010), and enzymes produced from co-metabolism phenomenon (Leys et al., 2008). Table 1 itemizes bacteria species known to degrade phenanthrene. Production of biosurfactants which increases the surface area of the hydrophobic pollutants, desorbs the pollutants from surface and makes hydrophobic pollutants to become soluble (Alrumman et al., 2015). The cumulative effect of biosurfactant production is to overcome mass transfer limitation for metabolizable phenanthrenes (Bustamante et al., 2012; Gutierrez et al., 2013; Fenibo et al., 2019; Khajavi-Shojaei et al., 2020). Another, mechanisms which microbes employ to increase bioavailability of pollutants is by modifying their cell surface properties such that their cell membranes becomes more hydrophobic (Delille et al., 2002). The effect of this microbial strategy is evidenced by the elicitation of cell bound formation of lypopolysacharides, fatty acids, glycolipids, lipoteichoic acids, lipoglycans and neutral lipids (Van Hamme et al, 2003). Altered cell surface can lead to biofilm formation and enhance cell colonization and spread (Isola et al., 2008). Biofilms serves as a protection state against toxicity of pollutants and chemicals and beyond this engender metabolite exchange, nutrient accession and lateral gene transfer (Kostka et al., 2011). According to Johnsen and Karison (2004), biofilm formation on PAHs' crystals may cause mass transfer of PAHs crystals directly into the bacterial cells thus favouring PAH availability. This confirms that biofilm formation greatly influences substrate (PAH) availability (Johnsen and Karison 2004). 
Table 1. Reported phenanthrene-degrading bacteria

\begin{tabular}{|c|c|c|}
\hline Species & Note & Reference \\
\hline $\begin{array}{l}\text { Acidovorax delafieldii } \mathrm{P} 4-1 \\
\text { Arthrobacter sulphureus } \mathrm{RKJ} 4\end{array}$ & $\begin{array}{l}\text { Phenanthrene degradation was enhanced by the addition of } \\
\text { Triton X-100. RKJ4 displays cometabolic degradation of } \\
\text { phenanthrene }\end{array}$ & $\begin{array}{l}\text { Samanta et al. } \\
\text { (1999) }\end{array}$ \\
\hline Ochrobactrum spp. & $\begin{array}{l}\text { Found in petroleum contaminated soil with phenanthrene } \\
\text { degrading ability }\end{array}$ & Liang et al. (2021) \\
\hline Pseudomonas sp. Lphe-2 & $\begin{array}{l}\text { A bacterium strain, isolated from coking plant with the } \\
\text { express ability to degrade phenanthrehe }\end{array}$ & JI et al. (2020) \\
\hline $\begin{array}{l}\text { Burkholderia cocovenenans BU- } \\
3\end{array}$ & $\begin{array}{l}\text { Isolated from petroleum polluted soil and degraded } \\
\text { phenanthrene by } 95 \% \text { at a rate of } 4.2 \mathrm{mg} / \mathrm{h}\end{array}$ & Wong et al. (2002) \\
\hline Diaphorobacter sp. YM-6 & $\begin{array}{l}\text { Bacteria strain found in PAH-contaminated sediment with } \\
\text { phenanthrene assimilation competence }\end{array}$ & Wang et al. (2020) \\
\hline Janibacter sp. YY-1 & $\begin{array}{l}\text { A dibenzofuran-degrading bacterium that has the ability to } \\
\text { cometabolize phenanthrene in soil }\end{array}$ & $\begin{array}{l}\text { Yamazoe et al. } \\
\text { (2004) }\end{array}$ \\
\hline $\begin{array}{l}\text { Pseudomonas sp. strain MP6- } \\
0207\end{array}$ & $\begin{array}{l}\text { Bacterium found in engine oil-contaminated mangrove } \\
\text { swamp }\end{array}$ & $\begin{array}{l}\text { Chantarasiri and } \\
\text { Campus (2020) }\end{array}$ \\
\hline Bacillus thuringiensis & $\begin{array}{l}\text { Collected from crude oil contaminated soil with proven } \\
\text { competence of degrading phenanthrene }\end{array}$ & $\begin{array}{l}\text { Abdel-Razeka et } \\
\text { al. (2020) }\end{array}$ \\
\hline $\begin{array}{l}\text { Mycobacterium vanbaalenii } \\
\text { PYR-1 }\end{array}$ & $\begin{array}{l}\text { A multi-PAH-degrading bacterium with functional genes } \\
\text { that degrade phenanthrene }\end{array}$ & $\begin{array}{l}\text { Stingley et al. } \\
\text { (2004) }\end{array}$ \\
\hline Sphingobium yanoikuyae SJTF8 & $\begin{array}{l}\text { Isolated and characterized as utilizer of phenanthrene as sole } \\
\text { carbon source. }\end{array}$ & Yin et al. (2020) \\
\hline Pseudomonas putida OUS82 & $\begin{array}{l}\text { A model bacterium isolated from oil contaminated soil and } \\
\text { used for the study of phenanthrene and naphthalene } \\
\text { assimilation }\end{array}$ & Tay et al. (2014) \\
\hline $\begin{array}{l}\text { Paeniglutamicibacter terrestris } \\
\text { sp. ANT13_2 } 2^{\mathrm{T}}\end{array}$ & $\begin{array}{l}\text { A constituent of phenanthrene-degrading consortium from } \\
\text { Antarctic soil }\end{array}$ & $\begin{array}{l}\text { Sakdapetsiri et al. } \\
\text { (2021) }\end{array}$ \\
\hline $\begin{array}{l}\text { Pseudomonas } \\
\text { ATAI19 }\end{array}$ & $\begin{array}{l}\text { Demonstrates dioxygenase activity with the ability of } \\
\text { producing biosurfactants and degrading phenanthrenes }\end{array}$ & et al. \\
\hline $\begin{array}{l}\text { Sphingomonas paucimobilis } \\
\text { EPA505 }\end{array}$ & Isolated from creosote and grow effectively on phenanthrene & Story et al. (2004) \\
\hline
\end{tabular}




\begin{tabular}{lll}
\hline Pseudomonas fluorescens AH-40 & $\begin{array}{l}\text { Isolated from crude oil polluted soil which consumed } \\
\text { phenanthrene as a source of carbon and energy }\end{array}$ & $\begin{array}{l}\text { Mawad et al. } \\
(2020)\end{array}$ \\
$\begin{array}{l}\text { Stenotrophomonas maltophilia } \\
\text { C6 }\end{array}$ & $\begin{array}{l}\text { Initiate phenanthrene degradation via 1,2-;3,4- and 9,10- } \\
\text { dioxygenations }\end{array}$ \\
Streptomyces sp. MC1 & $\begin{array}{l}\text { Isolated from fuel contaminated soil and genetically } \\
\text { confirmed in degrading phenanthrene }\end{array}$ & Sineli et al. (2021)
\end{tabular}

\section{Environmental factors}

Key environmental factors that may influence PAH biodegradation are nutrient availability, presence of toxicants, oxygen content, temperature, $\mathrm{pH}$, moisture and soil particle characteristics. Nutrient availability reduces the high C:N ratio in phenanthrene contaminated environment (Marisnescus et al., 2011) thereby addressing the rate limiting factor, hence facilitating degradation rate. Optimal resource ratio and balance is very critical because excess of nutrient can be inhibitory since some microbes, such as fungi are known nutrient recyclers, specifically nitrogen (Sihag and Pathak, 2014). Toxicant presence, such as heavy metals, slows down metabolic activities and growth (Umrania, 2006). The type of metals, concentration and kind of microbes exposed to such toxicants influences the degree and mechanisms of toxicity. Oxygen as an electron acceptor influences phenanthrene degradation more than any other electron acceptor (Erdogan and Karaca, 2011). So, when oxygen becomes rate limiting, anaerobic respiration ensues starting with denitrification process according to the thermodynamic feasibility order: oxygen> nitrogen> manganese? iron> sulphate> carbondioxide (Coates et al., 1997). Temperature influences phenanthrene degradation rate by controlling the rate of enzyme reaction, increases the solubility of pollutants but decreases oxygen solubility (Tomei and Daugulis, 2013). Study on the effect of temperature has shown that the rate of biodegradation doubles per $10^{\circ} \mathrm{C}$ rise of temperature up to a maximum of about $65^{\circ} \mathrm{C}$ (Thapa et al., 2012). Though most biodegradation studies tend to focus on mesophilic temperatures, phenanthrene degradation had shown to occur at extreme temperatures (Simarro et al., 2012; Al-Mur et al., 2021).

Biodegradation of phenanthrenes and other hydrocarbons is being executed under a wide range of $\mathrm{pH}$ though optimal at the border of between of 6.5-8.5. However, fungi and sulphate reducing bacteria thrive best in acidic medium (Das et al., 2009). Studies have shown that $\mathrm{pH}$ affect nutrient (phosphorus) and metal mobility in soil and adsorption to soil apart from effect on microbial degradation (Bamforth and Singleton, 2005). Soil moisture influences the rate of phenanthrene degradation like other petroleum hydrocarbons by influencing solubility of concerned pollutants including osmotic pressure and soil pH (Ezeonu et al., 2012). The presence of water in pore spaces of soil affects exchange of oxygen (Nkeng et al., 2012). Oxygen is usually consumed faster in saturated condition when compared to when it is replenished in the soil vapour space thus leading to anaerobic condition. On the contrary, moisture content between 25-85\% of water holding capacity is optimal for biodegradation in soil (Mrozik et al., 2003). The water holding capacity is the percentage of water remaining in soil after it has been saturated and gravitational drainage has ended (Salleh et al., 2003). Soil moisture largely affects nutrient availability to microorganisms through its impact on diffusion, solubility and biological process (uptake) affecting ion flow in soil (Shukla et al., 2010). At low moisture content, nutrient supply rate to microbes is slow due to increased tortousity of ion movement, soil texture, organic matter content and biological activity (Bulmer and Simpson, 2005).

For enhanced degradation of phenanthrenes interaction of optimal environmental and biological factors is necessary. An environment characterized with nutrient availability (C:N:P ratio of around 100:10:1), temperature that will ensure phenanthrene solubility without affecting oxygen availability $\left(20-30{ }^{\circ} \mathrm{C}\right)$, a redox potential of $>50$ millivolts, $\mathrm{pH}$ of 6.5-8.0 and concentration of phenanthrene not more than $10 \%$, relative to the weight of the environmental medium would lead to fast reduction of phenanthrene reduction.

\section{Conclusion}

Global concern for the 16 priority PAHs, including phenanthrene calls for a sustainable approach in remediating them. One such approach is microbial biodegradation, involving bacteria and fungi, which use phenanthrene as their sole source of carbon and energy. The metabolites derived from phenanthrene metabolism has been shown to be more than thirty three. A central molecule from 1,2- and 3,4-dihydroxyphenanthrene is 1-hydroxy-2-naphthoic acid and marks the beginning of the lower metabolic pathway of phenanthrene. The equivalent metabolite from 9,10- 
dihydroxyphenanthrene is 2,2'-diphenic acid which produces intermediary compound as that of 1-hydroxy-2naaphthoic acid. Both of them yield phthalic acid and salicylic acid. Thus, 2,2-diphenic can serve as a reliable biomarker in an environment characterized with phenanthrene pollution.

\section{References}

Abdel-Razeka, A. S., El-Sheikhb, H. H., Suleimanb, W. B., Tahac, T. H., \& Mohameda, M. K. (2020).

Bioelimination of phenanthrene using degrading bacteria isolated from petroleum soil: safe approach. Desalination and Water Treatment, 181, 131-140.

Kovacs, A., Vasas, A., Hohmann, J. (2008). Natural phenanthrenes and their biological activity. Phytochemistry 69: 1084-1110

Ahmad, M., Yang, Q., Zhang, Y., Ling, J., Sajjad, W., Qi, S., Zhou, W., Zhang, Y., Lin, X., Zhang, Y. and Dong, J., 2019. The distinct response of phenanthrene enriched bacterial consortia to different PAHs and their degradation potential: a mangrove sediment microcosm study. Journal of hazardous materials, 380: 120863.

Al-Mur, B. A., Pugazhendi, A., \& Jamal, M. T. (2021). Application of integrated extremophilic (halo-alkalothermophilic) bacterial consortium in the degradation of petroleum hydrocarbons and treatment of petroleum refinery wastewater under extreme condition. Journal of Hazardous Materials, 125351.

Alrumman, S.A., Standing, D.B. and Paton, G.I. (2015). Effects of hydrocarbon contamination on soil microbial community and enzyme activity. Journal of King Saud University. 27:31-41.

Amini, I., Tahmourespour, A., \& Abdollahi, A. (2017). Biodegradation of polycyclic aromatic hydrocarbons by Pseudomonas species. Pollution, 3(1), 9-19.

Atagana, H. (2006). Biodegradation of polycyclic aromatic hydrocarbons in contaminated soil by biostimulation and bioaugmentation in the presence of copper (11) ions. World Journal of Microbiological Biotechnology 22:1145-1153.

Bai, X., Nie, M., Diwu, Z., Nie, H., \& Wang, Y. (2021). Enhanced degradation and mineralization of phenol by combining two highly efficient strains with divergent ring-cleavage pathways. Journal of Water Process Engineering, 39, 101743.

Bamforth, S. M. and Singleton, 1. (2005a). Naphthalene transformation by Pseudomonas at an elevated pH. Journal of Chemical Technology and Biotechnology. 80(5): 140-152.

Becher, D., Specht, M., Hammer, E., Francke, N., Schaver, F. (2000). Cometabolic degradation of dibenzofuran by biphenyl-cultivated Ralstonia sp. Strain SBUC 290. Applied Environmental Microbiology. 66:4528-4531.

Bhuyan, K., \& Giri, A. (2020). Polycyclic Aromatic Hydrocarbon Compounds as Emerging Water Pollutants: Toxicological Aspects of Phenanthrene on Aquatic Animals. In Effects of Emerging Chemical Contaminants on Water Resources and Environmental Health (pp. 45-67). IGI Global.

Bulmer, C.E. and Simpson, D.G. (2005). Soil compaction and water content as factors affecting growth of lodge pole pine seedlings on sandy clay loam soil. Canadian Journal of soil science. 85:667-679. 
Bús, C., Tóth, B., Stefkó, D., Hohmann, J., \& Vasas, A. (2018). Family Juncaceae: Promising source of biologically active natural phenanthrenes. Phytochemistry Reviews, 17(4), 833-851.

Bustamante, M., Durin, N. and Diez, M.C. (2012). Biosurfactants are useful tools for the bioremediation of contaminated soil: a review. Journal of Soil Science and Plant Nutrition. 12 (4):667-687.

Chantarasiri, A., \& Campus, R. (2020). Enrichment and identification of phenanthrene-degrading bacteria isolated from the oil-stained engine sediment in the mangrove swamps of Thailand. Appl. Sci. Eng. Prog.

Coates, D.J., Woodward, J., Allen, J., Philip, P. and Lovey, D.R. (1997). Anerobic degradation of polycydic aromatic hydrocarbons and alkanes in petroleum-contaminated marine harbor sediments. Applied and Environmental Microbiology. 63(9):3589-3593.

Das, B. K., Roy, A., Koschorreck, M., Mandal, S. M., Wendt-Potthoff, K., \& Bhattacharya, J. (2009). Occurrence and role of algae and fungi in acid mine drainage environment with special reference to metals and sulfate immobilization. water research, 43(4), 883-894.

Delille, D., Delille, B. and Pelletiier, E. (2002). Effectiveness of Bioremediation of crude oil contaminated subantarctic intertidal sediment: the microbial response. Microbial Ecology. 44:118-128.

Erdogan, E.E. and Karaca, A. (2011). Bioremediation of crude oil polluted soils. Asian Journal of Biotechnology. 3(3):206-213.

Esedafe, W.F., Fagade, O.E., Umaru, F.F and Akinwotu, O. (2015). Bacterial degradation of the polycyclic aromatic hydrocarbon (PAH)-fraction of refinery effluent. International Journal of Environmental Bioremediation and Biodegradation. 3(1):23-27.

Ezeonu, C.S., Onwurah, I.N.E. and Oje, O.A. (2012). Compressive perspectives in bioremediation of crude oil contaminated environments. International Journal of Environmental Bioremediation and Biodegradation. 10:143-184.

Gao, S., Seo, J. S., Wang, J., Keum, Y. S., Li, J., \& Li, Q. X. (2013). Multiple degradation pathways of phenanthrene by Stenotrophomonas maltophilia C6. International biodeterioration \& biodegradation, 79, 98-104.

Gran-Scheuch, A., Fuentes, E., Bravo, D. M., Jiménez, J. C., \& Pérez-Donoso, J. M. (2017). Isolation and characterization of phenanthrene degrading bacteria from diesel fuel-contaminated Antarctic soils. Frontiers in microbiology, 8, 1634.

Gupta, A., Singh, A., \& Mishra, V. K. (2021). Sources, fate, and treatment of polycyclic aromatic hydrocarbons from the polluted environment. In Microbe Mediated Remediation of Environmental Contaminants (pp. 369-379). Woodhead Publishing.

Gutierrez, T., Berry, D., Yang, T., Mishamandani, S., McKay, L., Teske, A. and Aitken, M.D. (2013). Role of bacteria exoploysaccharides (EPS) in the fate of oil released during the deepwater horizon oil spill. Plos One. $8(6): \mathrm{e} 67717$.

Habe, H. and Omori, T. (2003). Genetics of polycyclic aromatic hydrocarbon on metabolism in diverse aerobic bacteria. Bioscience, Biotechnology and Biochemistry. 67(2):225-243.

Huang, X., Shi, J., Cui, C., Yin, H., Zhang, R., Ma, X., \& Zhang, X. (2016). Biodegradation of phenanthrene by Rhizobium petrolearium SL-1. Journal of applied microbiology, 121(6), 1616-1626. 
Igwo-Ezikpe, M.M., Okpuzor, J., Awodele, O., Nwaokorie, F.O., Foowora, M.A. and Akinbo, M.O. (2010). Prevalence of polycyclic aromatic hydrocarbons (PAHs) degrading bacteria in contaminated tropical soil in Lagos, Nigeria: involvement of plasmid in degradation. International Journal of Biological and Chemical Sciences. 4(6):2133-2145.

Isola, T.M.K., Enola, K.T.T., Olayemi, A.B. and Igunnugbemi, O.O. (2008). Response of resident bacteria of a crude oil-polluted river to diesel oil. American-Eurasian Journal of Agronomy. 1(1):06-09.

Ji, D., Mao, Z., He, J., Peng, S., \& Wen, H. (2020). Characterization and genomic function analysis of phenanthrene-degrading bacterium Pseudomonas sp. Lphe-2. Journal of Environmental Science and Health, Part A, 55(5), 549-562.

Jia, X., He, Y., Jiang, D., Liu, C., \& Lu, W. (2019). Construction and analysis of an engineered Escherichia coliPseudomonas aeruginosa co-culture consortium for phenanthrene bioremoval. Biochemical Engineering Journal, 148, 214-223.

Johnsen, A.R. and Karison, U. (2004). Evaluation of bacteria strategies to promote the bioavailability of polycyclic aromatic hydrocarbons. Applied Microbiology and Biotechnology. 63:452-459.

Khajavi-Shojaei, S., Moezzi, A., Enayatizamir, N., \& Mokhtari, B. (2020). Biodegradation and phytotoxicity assessment of phenanthrene by biosurfactant-producing Bacillus pumilus 1529 bacteria. Chemistry and Ecology, 36(5), 396-409.

Kostka, J.E., Prakash, O., Overholt, W.A., Green, S.J., Freyer, G., Caion, A., Delgardio, J., Norton, N., Hazen, T.C. and Huettel, M. (2011). Hydrocarbon-degradiang bacteria and the bacterial community response in Gulf of Mexico Beach sands impacted by the deepwater horizon oil spill. Applied and Environmental Microbiology. 7(22):7962-7974.

Kumar, A., Bisht B.S., Joshi, V.D. and Dhewa, T. (2011). Review on bioremediation of polluted environment: a management tool. International Journal of EnvironmentalSciences. 196:1079-1093.

Kúsz, N., Stefkó, D., Barta, A., Kincses, A., Szemerédi, N., Spengler, G., Hohmann, J. and Vasas, A., 2021. Juncaceae Species as Promising Sources of Phenanthrenes: Antiproliferative Compounds from Juncus maritimus Lam. Molecules, 26(4), p.999.

Leys, N., Ryngaert, A., Bastiaens, L., Wattiau, P., Top, E.V., Verstraete, W. and Springael, D. (2008). Occurrence and community composition of fast-growing Mycobacterium in soils contaminated with polycyclic aromatic hydrocarbons. FEMSMicrobiology Ecology. 51:373-388.

Liang, J., Gao, S., Wu, Z., Rijnaarts, H. H., \& Grotenhuis, T. (2021). DNA-SIP identification of phenanthrenedegrading bacteria undergoing bioaugmentation and natural attenuation in petroleum-contaminated soil. Chemosphere, 266, 128984.

Lundstedt, S., Haylund, P. and O'bery, L. (2003). Degradation and formation of polycyclic aromatic compounds during bioslurry treatment of an acid aged gasworks soil. Environmental Toxicological Chemistry. 22:14131420 .

Mangwani, N., Shukla, S. K., Rao, T. S., \& Das, S. (2014). Calcium-mediated modulation of Pseudomonas mendocina NR802 biofilm influences the phenanthrene degradation. Colloids and surfaces B: Biointerfaces, 114, 301-309. 
Marinescus, M., Toti M., Tanase V., Plopeanu, G., Calcui I. and Marinescu M. (2011). The effect of crude oil pollution on physical and chemical characteristics of soil. Research Journal of Agricultural Science.43(3):124-129.

Mawad, A. M., Abdel-Mageed, W. S., \& Hesham, A. E. L. (2020). Quantification of naphthalene dioxygenase $(\mathrm{NahAC})$ and catechol dioxygenase $(\mathrm{C} 23 \mathrm{O})$ catabolic genes produced by phenanthrene-degrading Pseudomonas fluorescens AH-40. Current Genomics, 21(2), 111-118.

Mishra, A., Rathour, R., Singh, R., Kumari, T., \& Thakur, I. S. (2019). Degradation and detoxification of phenanthrene by actinobacterium Zhihengliuella sp. ISTPL4. Environmental Science and Pollution Research, 1-12.

Mrozik, A., Piotrowska-Seget, Z. and Labuzek, S. (2003). Review: bacterial degradation of polycyclic aromatic hydrocarbons. Polish Journal of Environmental Studies, 12(1): 15-25.

Nkeng, G.E., Nkwelang, G. and Mathew, O. (2012). Bioremediaiton of petroleum refinery oily sludge in tropical soil. Scientific Reports. 1(2): 60-164.

Okpokwasili, G. C. and Nkweke, C. O. (2005). Microbial growth and substrate utilization kinetics. African Journal of Biotechnology. 4:305-317

Pagnout, C., Frache, G., Poupin, P., Maunit, B., Muller, J. F. and Férard, J. F. (2007). Isolation and characterization of a gene cluster involved in PAH degradation in Mycobacterium sp. strain SNP11: expression in Mycobacteriumsmegmatis mc(2)155. Research in Microbiology.158 (2):175-86.

Pandey, P., Pathak, H., \& Dave, S. (2016). Microbial ecology of hydrocarbon degradation in the soil: a review. Research Journal of Environmental Toxicology, 10(1), 1.

Petrovic, O., Knezevic, P., Markovic, J. and Ronceric, S. (2008), screening method for detection hydrocarbonoxidizing bacteria in oil contaminated water and soil specimens. Journal of Microbiological Methods. $74: 110-113$

Poater, J., Duran, M., \& Solà, M. (2018). Aromaticity determines the relative stability of kinked vs. straight topologies in polycyclic aromatic hydrocarbons. Frontiers in chemistry, 6, 561.

Pradhan, E., Lee, S., Choi, C. H., \& Zeng, T. (2020). Diboron-and diaza-doped anthracenes and phenanthrenes: their electronic structures for being singlet fission chromophores. The Journal of Physical Chemistry A, 124(40), 8159-8172.

Raissa, K. M., Augustin, M. and Benoit N.M. (2012). Naphthalene biodegradation by microbial consortia isolated from soils in Ngaoundere (Cameron). International Journal of Environmental Science, 3(1):120-127.

Sakdapetsiri, C., Kuntaveesuk, A., Ngaemthao, W., Suriyachadkun, C., Muangchinda, C., Chavanich, S., Viyakarn, V., Chen, B. and Pinyakong, O., 2021. Paeniglutamicibacter terrestris sp. nov., isolated from phenanthrenedegrading consortium enriched from Antarctic soil. International Journal of Systematic and Evolutionary Microbiology, p.004689.

Salleh, A.B., Ghazali, F.M., Abd Rahman, R.N.Z. and Basri, M. (2003). Bioremediaiton of petroleum hydrocarbon pollution. Indian Journal of Biotechnology. 2:411-425.

Samanta, S., Chakraborti, A. \& Jain, R. Degradation of phenanthrene by different bacteria: evidence for novel transformation sequences involving the formation of 1-naphthol. Appl Microbiol Biotechnol 53, 98-107 (1999). 
Sei, K., Sugimoto, Y., Mori, K., Marki, H. and Kohno, T. (2003). Monitoring of alkane degrading bacteria in a sea water microcosm during crude oil degradation by polymerase chain reaction based on alkane-catabolic genes. Environmental Microbiology. 5:517-522.

Semple, K.T., Morriss, W.J. and Paton, G.I. (2003). Bioavailability of hydrophobic organic contaminants in soils: fundamental concept and techniques for analysis. European Journal of soil Science. 54:809-818.

Seo, J.C., Keum, Y.S. and Li, Q.S. (2009). Bacteria degradation of aromatic compounds. International Journal of Environmental Research and Public Health. 6:278-309.

Shi, Y., Zhang, B., Lu, Y., Qian, C., Feng, Y., Fang, L., Ding, Z. and Cheng, D., 2017. Antiviral activity of phenanthrenes from the medicinal plant Bletilla striata against influenza A virus. BMC Complementary and Alternative Medicine, 17(1), pp.1-14.

Shukla, K.P., Singh, K.N. and Sharma, S. (2010). Bioremediation: development, current practices and perspectives. Genetic Engineering and Biotechnology Journal. 3:1-20.

Sihag, S. and Pathak, H. (2014). A review: biodegradation of polyaromatic hydrocarbons. American Journal of Earth Science. 1(1):9-20.

Simarro, R., Gonzalez, N., Bautista, L.F. and Molina, M.C. (2012). Biodegradation of high molecular-weight polycyclic aromatic hydrocarbons by a wood-degrading consortium at low temperatures. FEMS Microbiology Ecology. 83(2):438-449.

Stingley RL, Khan AA, Cerniglia CE. Molecular characterization of a phenanthrene degradation pathway in Mycobacterium vanbaalenii PYR-1. Biochem Biophys Res Commun. 2004 Sep 10;322(1):133-46.

Story SP, Kline EL, Hughes TA, Riley MB, Hayasaka SS. Degradation of aromatic hydrocarbons by Sphingomonas paucimobilis strain EPA505. Arch Environ Contam Toxicol. 2004 Aug;47(2):168-76.

Strand, J.L., Paton, G.I., and Semple, K.T. (2007). Microbe-aliphatic hydrocarbon interaction in soil: implication for biodegradation and bioremediation. JournalofAppliedMicrobiology. 102(5):1239-1253.

Thapa B., Kumar K.C.A. and Ghimire, B. (2012). A review on bioremediation of petroleum hydrocarbon contaminants in soil. Journal of Science, Engineering and Technology. 8(1):164-170.

Tomei, M.C. and Daugulis, A.J. (2013). Ex-situ bioremediation of contaminated soils: an overview of conventional and innovative technologies. Critical Reviews in Environmental Sciences and Technology. 43:2107-2139.

Tay, M., Roizman, D., Cohen, Y., Tolker-Nielsen, T., Givskov, M., \& Yang, L. (2014). Draft genome sequence of the model naphthalene-utilizing organism Pseudomonas putida OUS82. Genome announcements, 2(1).

Tóth, B., Hohmann, J., \& Vasas, A. (2017). Phenanthrenes: a promising group of plant secondary metabolites. Journal of Natural Products, 81(3), 661-678.

Ukiwe, L.N., Egereonu, U.U., Njoku, P.C., Nwoko, C.I.A. and Allinor, J.I. (2013). Polycyclic aromatic hydrocarbons degradation techniques: a review. International Journal of Chemistry. 5(4):43-55.

Umrania, V. V. (2006). Bioremediation of toxic heavy mental using acidothermophilic autotrophes. Bioresource Technology, 97:123-1242. 
Van Hamme, J.D.V., Singh, A. and Ward, O.P. (2003). Recent advances in petroleum microbiology. Microbiology and Molecular Biology Reviews. 67(4):503-549.

Vinas, M., Sabate, J. Espuny, M.J., Solanas, A.M. (2005). Bacterial community dynamics and polycyclic aromatic hydrocarbon degradation during bioremediation of heavily creosote-contaminated soil. Applied and Environmental Microbiology. 71(11):7008- 7018.

Waigi, M. G., Kang, F., Goikavi, C., Ling, W., \& Gao, Y. (2015). Phenanthrene biodegradation by sphingomonads and its application in the contaminated soils and sediments: a review. International Biodeterioration \& Biodegradation, 104, 333-349.

Wang, J., Zhong, Y., Carmella, S.G., Hochalter, J.B., Rauch, D., Oliver, A., Jensen, J., Hatsukami, D.K., Upadhyaya, P., Hecht, S.S. and Zimmerman, C.L., 2012. Phenanthrene metabolism in smokers: use of a two-step diagnostic plot approach to identify subjects with extensive metabolic activation. Journal of Pharmacology and Experimental Therapeutics, 342(3), pp.750-760.

Wang, P., Zhang, Y., Jin, J., Wang, T., Wang, J., \& Jiang, B. (2020). A high-efficiency phenanthrene-degrading Diaphorobacter sp. isolated from PAH-contaminated river sediment. Science of The Total Environment, $746,140455$.

Wong, J.W.C., Lai, K.M., Wan, C.K. et al. Isolation and optimization of PAH-degradative bacteria from contaminated soil for pahs bioremediation. Water, Air, \& Soil Pollution 139, 1-13 (2002).

Xin, X., Huang, G., \& Zhang, B. (2020). Review of aquatic toxicity of pharmaceuticals and personal care products to algae. Journal of Hazardous Materials, 124619.

Yamazoe A, Yagi O, Oyaizu H. Degradation of polycyclic aromatic hydrocarbons by a newly isolated dibenzofuranutilizing Janibacter sp. strain YY-1. Appl Microbiol Biotechnol. 2004 Aug;65(2):211-8.

Yin, C., Xiong, W., Qiu, H., Peng, W., Deng, Z., Lin, S., \& Liang, R. (2020). Characterization of the phenanthrenedegrading sphingobium yanoikuyae sjtf8 in heavy metal co-existing liquid medium and analysis of its metabolic pathway. Microorganisms, 8(6), 946.

Zeb, M. A., Murtaza, G., Hussain, M. A., Kubra, K. T., Muvhiiwa, R., De Kock, L. A., \& Hassard, F. (2020). A comprehensive adsorption study of 1-Hydroxy-2-Naphthoic acid using cost effective engineered materials. Environmental Technology \& Innovation, 19, 100881.

Zhou, F., Last, R. L., \& Pichersky, E. (2021). Degradation of Salicylic Acid to Catechol in Solanaceae by SA 1Hydroxylase. Plant Physiology 2021: 1-16.

Zindler, F., Glomstad, B., Altin, D., Liu, J., Jenssen, B. M., \& Booth, A. M. (2016). Phenanthrene bioavailability and toxicity to Daphnia magna in the presence of carbon nanotubes with different physicochemical properties. Environmental science \& technology, 50(22), 12446-12454. 